\title{
External ocular motor palsies in ophthalmic zoster: a review
}

\author{
‥ J. MARSH, B. DULlEY, AND V. KELLY \\ From the External Diseases Clinic, Department of Clinical Ophthalmology, \\ Moorfields Eye Hospital, City Road, London
}

SUMMARY Seventy-seven new patients suffering from ophthalmic zoster and a selected group of 69 old patients were carefully examined with regard to external ocular movements. An incidence of $31 \%$ of ocular pareses was found in the new patients, and 58 in all were analysed. We were surprised to find several of these were contralateral and bilateral palsies. $28 \%$ of the palsies were asymptomatic, due to diplopia being present only in extremes of gaze and the rapid development of suppression in the affected eye. The theories of aetiology of these pareses are discussed.

Herpes zoster ophthalmicus produces widely varying lesions of the eye in $50 \%$ of cases (Edgerton, 1945a) and rarely involves other parts of the central nervous system (Edgerton, 1945b; Walsh and Hoyt, 1969; Thomas and Howard, 1972; Marsh, 1976a). It is thought to arise by reactivation of varicella virus lying latent in the trigeminal ganglion after a prior attack of chicken pox (Garland, 1943; HopeSimpson, 1965), the virus replicating and migrating peripherally to skin, orbit, and centrally to the brain stem (Godfredson, 1948; Esiri and Tomlinson, 1972).

The cranial involvement takes many forms. A meningoencephalitis may develop (Schiff and Brain, 1930; Krumholz and Luihan, 1945; WorsterDrought and Sargent, 1949; Appelbaum et al., 1962; Rose et al., 1964; Norris et al., 1970). Contralateral hemiplegia occurs rarely, either in an isolated form (Baudouin and Lantvejoul, 1919; Rollett and Colrat, 1926; Biggart and Fisher, 1938; Hughes, 1951; Cope and Jones, 1954; Minton, 1956; Laws, 1960; Acers, 1964), or accompanied by hemianopia (Franceschetti et al., 1955), aphasia and agraphia (Gordon and Tucker, 1945; Leonardi, 1949; Anastostopoulos et al., 1958). Other cranial nerves may be implicated simultaneously. Optic neuritis has been well described (Duke-Elder, 1940; Edgerton, 1945c; Pemberton, 1964; Harrison, 1965; Ramsell, 1967). The VIIth nerve is occasionally involved (Hunt, 1909; Edgerton, 1945d), and a contralateral VIIth nerve paresis has been described in 1 case (Norris et al., 1970). Third, IVth, and VIth nerve palsies occur more frequently (Edgerton, 1945e;

Address for reprints: R. J. Marsh, FRCS, Department of Clinical Ophthalmology, Moorfields Eye Hospital, City Road, London EC1V 2PD
Goldsmith, 1968), the IIIrd being the commonest (Kelly and Dulley, 1975). All 3 may be involved together as a total ophthalmoplegia and are usually accompanied by proptosis (Carmody, 1937; Edgerton, 1945f; Lister, 1948; Pincus, 1949; Von Siegert, 1964). Many series have been published giving the incidence of extraocular muscle palsies as $5 \%$ (Hybord, 1872; Flament and Bronner, 1974), 7\% (Desirat, 1903; Worster-Drought, 1923), 10\% (Nover, 1970), 12\% (Rebattu et al., 1933), 13\% (Edgerton, 1945g), and 14\% (Hunt, 1909).

In this paper we present our own series based on a large number of patients.

\section{Patients}

The patients included in this study were drawn from those attending the zoster division of the External Diseases Clinic at Moorfields Eye Hospital, City Road, London, over a 4-year period. All were carefully examined with special reference to severity of rash, degree of neuralgia, the presence of nasociliary or lid margin involvement, episcleritis/ scleritis, keratitis, iritis, and iris atrophy, and any complaints of diplopia were noted. A special note was added on the sectoral distribution of the lesions. Corneal sensation was measured centrally and in the 4 outer quadrants with the aesthesiometer of Cochet and Bonnet. Special investigations included haemoglobin concentration, ESR, differential white count, blood film, plasma protein electrophoretic strip, blood sugar, liver function tests and chest $x$-ray.

Two of the authors examined in detail the ocular movements of all new patients passing through the clinic in an 8-month period (77 patients) and a 
a) Ipsilateral Cases (34)

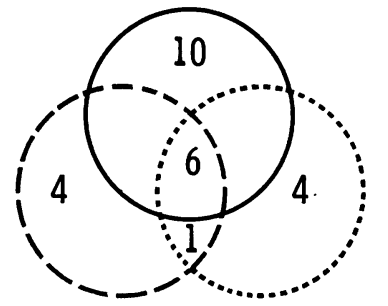

b) Contralateral Cases

(9)

Key:

IIIrd nerve

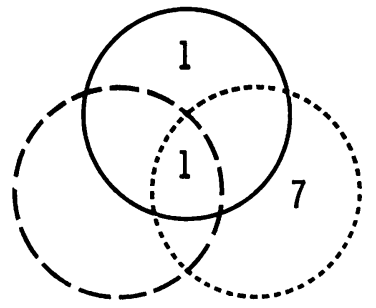

Fig. 1 Distribution of nerve involvement in external ocular palsies

selected group of old patients attending for follow-up (69 patients), many of whom had been previously diagnosed as having ocular palsies due to zoster. Tests were carried out at each attendance regardless of subjective symptoms and included cover test, ocular movements, convergence, assessment of binocular function, and Lees screen. A note was also made of the position of the upper lid margin.

\section{Results}

Twenty-two cases of paresis were found in the 77 new patients examined, giving an incidence of $29 \%$. A total of 58 cases of external ocular muscle paresis were discovered among the new and old patients. Forty-two of them complained of diplopia, 32 constantly. Sixteen of the patients were asymptomatic, although 8 admitted to diplopia on testing in extremes of gaze. Careful analysis of the 58 pareses showed they tended to fall into 5 categories (Table 1). The different cranial nerves involved in the ipsilateral and contralateral groups are analysed in the Venn diagram (Fig. 1). The third category revealed slow recovery of the original ipsilateral paresis, and always a contralateral IIIrd nerve palsy superseded, although the same branch was not necessarily affected on each side (Table 2). A small percentage of cases had the same muscle paresis on each side from the beginning, but other underactions were present, usually on the side affected by the rash. Complete ophthalmoplegia was accompanied by proptosis in 3 of the 4 cases seen, and 1 of these in fact had bilateral ophthalmoplegia and proptosis.

Fig. 2 shows the age distribution of the patients

Table 1 Laterality of external ocular palsy

\begin{tabular}{|c|c|c|c|c|c|}
\hline & Ipsilateral & Contralateral & $\begin{array}{l}\text { Ipsilateral } \\
\text { becoming } \\
\text { contralateral }\end{array}$ & Bilateral & $\begin{array}{l}\text { Complete } \\
\text { ophthal- } \\
\text { moplegia }\end{array}$ \\
\hline $\begin{array}{l}\text { No. of } \\
\text { cases }\end{array}$ & 34 & 9 & 6 & 5 & 4 \\
\hline
\end{tabular}

with palsies, and it should be noted that the youngest was 46.

All the pareses were detected within the first week of the rash, although it was often difficult to examine

Table 2 Ipsilateral palsies becoming contralateral

\begin{tabular}{|c|c|c|c|}
\hline Cases & Ipsilateral & & Contralateral \\
\hline $\left.\begin{array}{l}1 \\
2\end{array}\right\}$ & III & $\rightarrow$ & III \\
\hline 3 & VI & $\rightarrow$ & III and IV \\
\hline $\left.\begin{array}{l}4 \\
5\end{array}\right\}$ & III and VI & $\rightarrow$ & III and VI \\
\hline 6 & III, VI, and IV & $\rightarrow$ & III and VI \\
\hline
\end{tabular}

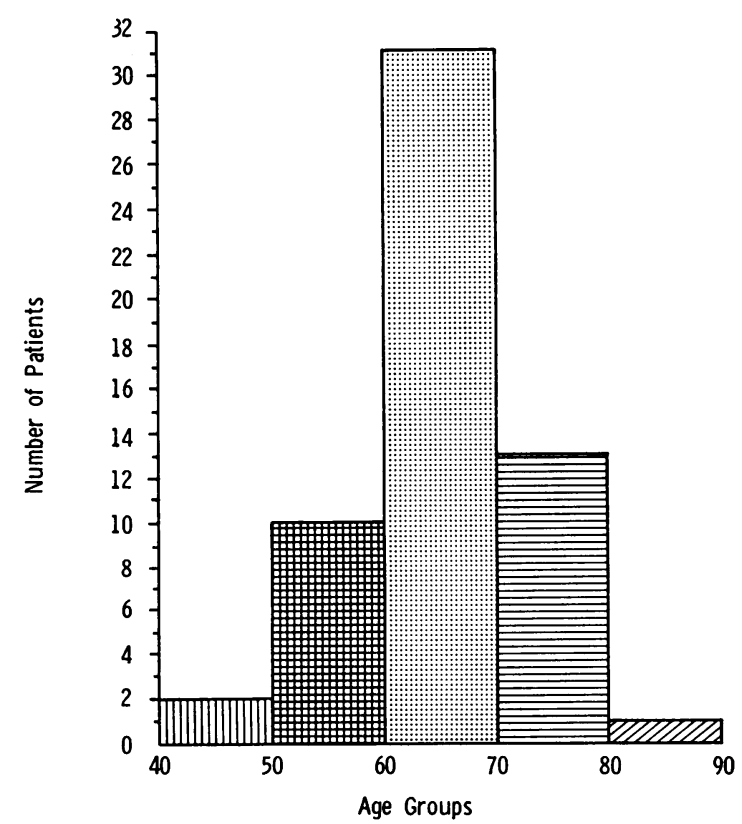

Fig. 2 Histogram of age distribution in zoster 


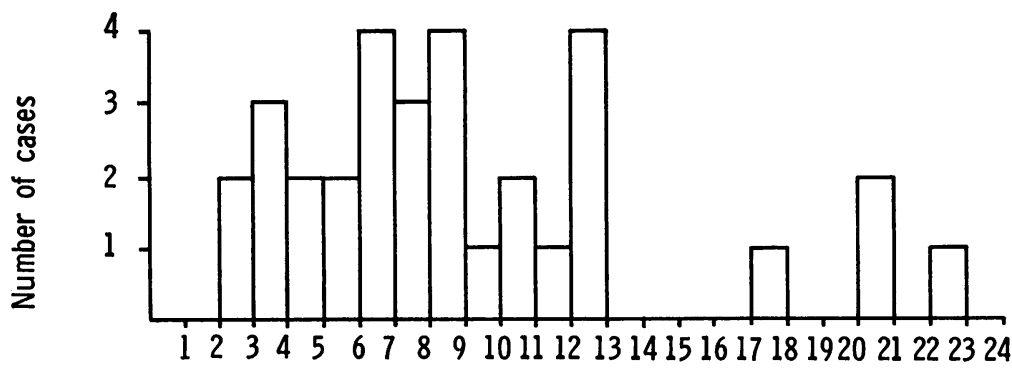

Fig. 3 Histogram of duration of diplopia in ophthalmic zoster

Months after onset of disease

eye movements at this stage owing to the lid swelling and malaise of many of the patients.

Fig. 3 shows the duration of symptoms, and it is significant that there were only 3 cases lasting for more than 18 months. However, an orthoptic defect could always be found in all patients despite the excellent subjective recovery.

The incidence of other ocular complications of zoster in the ocular motor palsy group was compared with those occurring in a comparison group of 46 patients seen at the same time with no ocular motor defect. The results and statistical analyses are depicted in Table 3. There was no clear relationship between any of the sectoral lesions and a particular external ocular muscle underaction. Neither was there any significant correlation with the results of the special investigations.

Three patients had ipsilateral VIIth nerve paralysis without auricular involvement. A further 3 developed contralateral hemiplegia within 1 month of the onset of zoster, and a fourth developed an ipsilateral hemiplegia 2 years after the rash.

Table 3 The association of external ocuiar palsies with other complications of ophthalmic zoster

\begin{tabular}{lrrll}
\hline $\begin{array}{l}\text { Complications of } \\
\text { ophthalmic zoster }\end{array}$ & \multicolumn{1}{c}{$\chi^{2}$} & Probability & Remarks \\
\hline Severity of zoster & 12.6 & $\mathbf{P}<0.001$ & Very highly significant \\
Neuralgia & 5.9 & $0.05>\mathrm{P}>0.01$ & Highly significant \\
Iritis & 12.6 & $\mathbf{P}<0.001$ & Very highly significant \\
Iris atrophy & 10.2 & $0.01>\mathrm{P}>0.001$ & Highly significant \\
Sphincter damage & 1.8 & $0.2>\mathrm{P}>0.1$ & Non-significant \\
Corneal reflex & 0.82 & $0.5>\mathrm{P}>0.3$ & Non-significant \\
Corneal involvement & 2.1 & $0.2>\mathrm{P}>0.1$ & Non-significant \\
Episcleritis & 0.2 & $0.7>\mathbf{P}>0.5$ & Non-significant \\
Lid involvement & 0.91 & $0.5>\mathbf{P}>0.3$ & Non-significant \\
\hline
\end{tabular}

\section{Discussion}

We found external ocular motor palsies in ophthalmic zoster to be more common than previously indicated. This was probably related to the detailed examination of eye movements in all patients. $28 \%$ were asymptomatic owing to the diplopia being present only in extremes of gaze, poor sight in the affected eye, or to the development of suppression at a late age. Recovery was excellent despite the fact that an objective defect could always be found on orthoptic examination. The presence of a squint was significantly associated with the severity of the rash and the later occurrence of severe neuralgia, iritis, and iris atrophy, whereas episcleritis, and corneal and lid involvement were of no greater frequency. No case was seen under the age of 40. Surprisingly we found some of the palsies to be bilateral and on the side opposite to the skin lesions.

\section{PATHOGENESIS}

To try to understand the cause of bilaterality of some of the palsies and their relationship to other complications of zoster it is necessary to consider the pathogenesis of the lesions.

Three pathogenic mechanisms should be considered for mediating neural damage in zoster. The first is a direct cytopathic effect from the virus itself on the surrounding neural tissue (Cope and Jones, 1954). The second is an allergic response of the central nervous system to the virus, which is not primarily vascular (Krumholz and Luihan, 1945; Appelbaum et al., 1962; Rose et al., 1964). The third attributes it to an occlusive vasculitis induced by the virus (Gordon and Tucker, 1945; Feyrter, 1954; Anastostopoulos et al., 1958; Wray, 1972). A fourth theory (for which there is little evidence) suggests the varicella/zoster virus activates another latent neuropathic virus within the brain (Appelbaum et al., 1962).

Virus may reach the brain in several ways and there cause direct cytopathic or allergic damage to 
the nervous tissue. The first is a retrograde spread of virus from the trigeminal ganglion to the Vth nerve nucleus. Here it reaches other cranial nerve nuclei, either by axonal spread along established interconnections (Biggart and Fisher, 1938; Godfredson, 1948; Goodbody, 1953), or by random spread (Cope and Jones, 1954; Acers, 1964). The former pathway could be along the proprioceptive neurones of the oculomotor muscles in the Vth nerve (Denny-Brown et al., 1944). Alternatively, virus may reach the brain by means of a basal meningoencephalitis, which is well described in the literature (Schiff and Brain, 1930; Wynne Parry and Laszlo, 1943; Gordon and Tucker, 1945; Godfredson, 1948; Hughes, 1951; Norris et al., 1970). The area chiefly involved is thought to be the pontine region (Worster-Drought, 1923). Many features can be attributed to this: headache, general malaise, pyrexia, bilaterality of lesions, multiple cranial nerve palsies, hemiplegia, CSF findings, and the rare cases of cranial nerve lesions secondary to a remote primary zoster lesion (Thomas and Howard, 1972; Keane, 1975). Against this theory is the delayed occurrence of many of the cranial nerve lesions, the lack of symptoms and signs of encephalitis in many of the patients, and the rarity of bilateral lesions other than oculomotor palsies. Thirdly, a separate cranial motor neuritis may occur simultaneously with the trigeminal lesion, presumably also owing to the presence of latent virus activated by the same unknown stimuli. This could be a satisfactory answer for contralateral palsies and the occurrence of lesions at a different level from the primary rash (Denny-Brown et al., 1944; Keane, 1975). However, it is somewhat unsatisfactory to postulate 2 distinct lesions and could not adequately explain the association of squints with other ocular complications of zoster.

The last pathogenic mechanism to be considered is that of occlusive vasculitis. Various sites have been prosposed. The earliest suggestion was that of the muscle cone and orbit with accompanying myositis, perineuritis, and thrombosis (Wyss, 1871; Abadie, 1898; Aubineau, 1914-15; Kreibig, 1938; Von Siegert, 1964). While this would be in keeping with the picture seen in total ophthalmoplegia with proptosis, iritis, and iris atrophy, it does not explain the isolated and contralateral ocular palsies we have seen or the rarer cases of contralateral hemiplegia.

The second site to be described was the cavernous sinus and orbit apex with involvement of the adjacent IIIrd, IVth, and VIth nerves (Rebattu et al., 1933; Edgerton, 1945g; Franceschetti et al., 1955; Walsh and Hoyt, 1969; Scheie, 1970). The difficulty here is to account for hemiplegias and the bilaterality of lesions, although it is true that the cavernous sinuses of both sides intercommunicate freely. The origins of the middle cerebral and ophthalmic arteries are here, and an ascending vasculitis may spread along these, with accompanying thrombosis (Gordon and Tucker, 1945; Anastostopoulos et al., 1958). This may be mediated by a granulomatous angiitis induced by the varicella/zoster virus, involving the carotid artery, ipsilateral to the involved eye and segmental (Rosenblum and Hadfield, 1972; Victor and Green, 1976). In favour of this theory is the delayed onset of contralateral hemiplegias, hemianopias, and aphasias secondary to damage in the region of the internal capsule, and the occurrence of ischaemic optic neuritis and iritis. But it is a rather unsatisfactory mechanism for evoking contralateral ocular palsies.

A third site of vasculitis in the brain stem has been described pathologically by Feyrter (1954). This would, of course, account for ipsilateral palsies, contralateral hemiplegias (from involvement of the corticospinal tract), and lesions of adjacent cranial nerve nuclei. A spillover of the vasculitis just the other side of the midline could give rise to the contralateral ocular palsies.

It is possible, of course, that the palsies are of a mixed aetiology and that all the mechanisms and sites mentioned are involved.

\section{TREATMENT}

In view of the satisfactory recovery without treatment in most cases the question arises, Is any necessary? The minority that suffer very troublesome diplopia may need temporary occlusions.

An overall therapeutic solution to zoster must include an effective, non-toxic, systemic antiviral agent which crosses the blood brain barrier. If given at the very onset of the disease it would prevent both the direct and allergic cytopathic effect of the virus on neural tissue and prevent the initiation of a seondary vasculitis by destroying the virus at an early stage. However, a problem will still exist if cases present later on when these changes have been initiated, especially the vasculitis. It would seem logical to use systemic steroid in cases of occlusive vasculitis, and it is almost certain that total ophthalmoplegia with proptosis and ischaemic papillitis comes into this category (Marsh, 1976b).

It is quite clear that much work needs to be done on the pathogenesis of zoster and its complications. The disease is still a great mystery and despite its clearly proved association with varicella virus the theory of latency is not proved. The connections between the virus and lesions seen are also not understood. Neither is it known whether continuing presence of virus is necessary for the production of chronic lesions. There are many difficulties in 
clarifying these issues. No animal model exists for zoster, and there is a great problem in obtaining postmortem information on well-documented patients with zoster, especially in processing material for immediate histological, virological, and immunological checking. It is to be hoped that advances in these techniques will provide the therapist with the information he needs for the effective handling of this disabling disease.

We thank Professor Barrie Jones and Mr Alan Bird for their encouragement, Mr R. Fisher for his help with the statistics, and Mrs Jane Field for secretarial assistance.

\section{References}

Abadie, J. (1898). Douleurs neuralgiques anciennes consécutives au zona guéris immédiatement par la ponction lombaire, Bulletin de la Société Française de Dermatologie et de Syphiligraphie, 10 April.

Acers, T. E. (1964). Herpes zoster ophthalmicus with contralateral hemiplegia. Archives of Ophthalmology, 71, 371-376.

Anastostopoulos, G., Routsonia, K., and Ierodiakonou, C. S. (1958). Ophthalmic herpes zoster with contralateral hemiplegia. Journal of Neurology, Neurosurgery and Psychiatry, 21, 210-212.

Appelbaum, E., Kreps, S. I., and Sunshine, A. (1962). A zoster encephalomyelitis. American Journal of Medicine, 32, 25-31.

Aubineau, E. (1914-15). Zona ophthalmique avec ophtalmoplégie. Clinique Ophtalmologique, 7, 513-514.

Baudouin, E., and Lantvejoul, P. (1919). Les troubles moteurs dans le zona. Gazette des Hôpitaux Civils et Militairés, 92, 1293-1295.

Biggart, J. H., and Fisher, J. A. (1938). Meningoencephalitis complicating herpes zoster. Lancet, 2, 944-945.

Carmody, R. F. (1937). Herpes zoster ophthalmicus complicated by ophthalmoplegia and exophthalmos. Archives of Ophthalmology, 18, 707-711.

Cope, S., and Jones, A. T. (1954). Hemiplegia complicating ophthalmic zoster. Lancet, 2, 898-899.

Denny-Brown, D., Adams, R. D., and Fitzgerald, P. J. (1944). Pathologic features of herpes zoster. Archives of Neurology and Psychiatry, 51, 216-231.

Desirat, A. J. (1903). Contribution à l'étude de quelques complications rares du zona ophtalmique, nevrite optique, ophtalmoplégies, paralysies éloignées, Thesis, Bordeaux, No. 126 , p. 179.

Duke-Elder, S. (1940). Textbook of Ophthalmology, Vol. 3, p. 2997. Kimpton: London.

Edgerton, A. E. (1945a). Herpes zoster ophthalmicus. Archives of Ophthalmology, 34, 47-48.

Edgerton, A. E. (1945b). Herpes zoster ophthalmicus. Archives of Ophthalmology, 34, 56-62.

Edgerton, A. E. (1945c). Herpes zoster ophthalmicus. Archives of Ophthalmology, 34, 60-61.

Edgerton, A. E. (1945d). Herpes zoster ophthalmicus. Archives of Ophthalmology, 34, 56.

Edgerton, A. E. (1945e). Herpes zoster ophthalmicus. Archives of Ophthalmology, 34, 57-58.

Edgerton, A. E. (1945f). Herpes zoster ophthalmicus. Archives of Ophthalmology, 34, 58.

Edgerton, A. E. $(1945 \mathrm{~g})$. Herpes zoster ophthalmicus. Archives of Ophthalmology, 34, 137.

Esiri, M. M., and Tomlinson, A. H. (1972). Herpes zoster; demonstration of virus in trigeminal nerve and ganglion by immunofluorescence and electron microscopy. Journal of Neurological Science, 15, 35-48.

Feyrter, F. (1954). Über das wesen des zoster. Virchows Archiv für pathologische Anatomie und Physiologie und für klinische Medizin, 325, 70-89.

Flament, J., and Bronner, A. (1974). Les complications neuro-ophtalmologiques du zona ophtalmique, Revista Oto-neuro-oftalmologica, 46, 53-64.

Franceschetti, A., de Morsier, G., and Forn, S. (1955). Hemianopsie homonyne et paralysies oculaire au cours d'un zona ophtalmique. Revista Oto-reuio-oftalmologica, 27, 330-333.

Garland, J. (1943). Varicella following exposure to herpes zoster. New England Journal of Medicine, 228, 336.

Godfredson, E. (1948). Pathogenesis of cranial nerve lesions, notably ophthalmoplegias complicating herpes zoster ophthalmicus. Acta Psychiatrica et Neurologica Scandinavica, 23, 69-77.

Goldsmith, M. O. (1968). Herpes zoster ophthalmicus with VIth nerve palsy. Canadian Journal of Ophthalmology, 3 , 279-283.

Goodbody, R. A. (1953). The pathology of acute herpes zoster ophthalmicus. Journal of Pathology and Bacteriology, 65, 221-227.

Gordon, I. R. S., and Tucker, J. D. (1945). Lesions of the central nervous system in herpes zoster. Journal of Neurology and Psychiatry, 8, 40-46.

Harrison, E. Q. (1965). Complications of herpes zoster ophthalmicus. American Journal of Ophthalmology, 60, 111-114.

Hope-Simpson, R. E. (1965). The nature of herpes zoster: a long-term study and a new hypothesis. Proceedings of the Royal Society of Medicine, 58, 9-20.

Hughes, W. N. (1951). Herpes zoster of the right trigeminal nerve with left hemiplegia. Neurology, 1, 167-169.

Hunt, J. E. (1909). The paralytic complications of herpes zoster of the cephalic extremity. Journal of the American Medical Association, 53, 1456-1457.

Hybord, A. (1872). Du zona ophtalmique et des lesions oculaire. Thesis, Paris, No. 232.

Keane, J. R. (1975). Delayed trochlear nerve palsy in a case of zoster oticus. Archives of Ophthalmology, 93, 382-383.

Kelly, V., and Dulley, B. (1975). Ocular motor defects associated with herpes zoster ophthalmicus. Orthoptics Past, Present and Future, Transactions of the IIIrd International Orthoptic Congress, Boston, pp. 367-377. Symposia Specialists, Stratton Intercontinental Medical Book Corporation: New York.

Kreibig, W. (1938). Histologische befunde bei herpes zoster ophthalmicus. Berichte der Deutschen Ophthalmologischen Gesellschaft, 52, 461-462.

Krumholz, S., and Luihan, J. A. (1945). Encephalitis associated with herpes zoster. Archives of Neurology and Psychiatry, 53, 59-67.

Laws, H. W. (1960). Herpes zoster ophthalmicus complicated by contralateral hemiplegia. Archives of Ophthalmology, 63, 273-280.

Leonardi, G. (1949). Diabete mellito regredito stontaneamente in coincidenza con la comparsa di focolai encefalo-malacici in un soggetto con pregresso 'herpes zoster'. Rassegna di Neurologia Vegetativa, 7, 197-204.

Lister, A. (1948). Herpes zoster with complete ophthalmolplegia. Transactions of the Ophthalmological Societies of the United Kingdom, 68, 287.

Marsh, R. J. (1976a). Ophthalmic herpes zoster. British Journal of Hospital Medicine, June, 609-618.

Marsh, R. J. (1976b). Current management of ophthalmic herpes zoster. Transactions of the Ophthalmological Societies of the United Kingdom, 96, 334-337.

Minton, J. (1956). A case of left herpes zoster ophthalmicus 
followed by virus encephalitis with right-sided anaesthesia, parasthesia and hemiplegia. Transactions of the Ophthalmological Societies of the United Kingdom, 76, 227-233.

Norris, F. J., Leonards, R., Calanchini, P. R., and Calder, C. D. (1970). Herpes zoster meningoencephalitis. Journal of Infectious Diseases, 122, 335-338.

Nover, A. (1970). Zoster und Auge. Klinische Monatsblätter für Augenheilkunde, 156, 305-317.

Pemberton, J. W. (1964). Optic atrophy with herpes zoster ophthalmicus. American Journal of Ophthalmology, 58, 852-854.

Pincus, J. M. (1949). Herpes zoster ophthalmicus: a case with manifold complications. American Journal of Ophthamology, 32, 130-134.

Ramsell, T. G. (1967). Complications of herpes zoster ophthalmicus. American Journal of Ophthalmology, 63, 1796-1798.

Rebattu, J., Mounier Kuhn, P., Dechaume, J., Bonnet, P., and Colrat, A. (1933). Les zonas cephaliques. Revista Otoneuro-oftalmologica, 9, 241-246.

Rollett, E., and Colrat (1926). Zona ophtalmique gauche, paralysie du moteur oculaire comme un hemiparesie droite. Archives d'Ophtalmologie et Revue Générale d'Ophtalmologie, 43, 437.

Rose, F. C., Brett, E. M., and Burston, J. (1964). Zoster encephalomyelitis. Archives of Neurology, 11, 155-172.

Rosenblum, W. I., and Hadfield, M. G. (1972). Granulomatous angiitis of the nervous system in cases of herpes zoster and lymphosarcoma. Neurology, 22, 348-354.
Scheie, H. G. (1970). Herpes zoster ophthalmicus. Transactions of the Ophthalmological Societies of the United Kingdom, 90, 899-930.

Schiff, C. I., and Brain, W. R. (1930). Acute meningoencephalitis associated with herpes zoster. Lancet, 2, 70.

Thomas, J. E., and Howard, J. M. (1972). Segmental zoster paresis: a disease profile. Neurology, 22, 439-466.

Victor, D. I., and Green, W. R. (1976). Temporal artery biopsy in herpes zoster ophthalmicus with delayed arteritis. American.Journal of Ophthalmology, 82, 628-630.

Von Siegert, P. (1964). Zoster exophthalmus und ophthalmoplegie. Klinische Monatsblätter für Augenheilkunde, 144, 54-58.

Walsh, F. B., and Hoyt, W. F. (1969). Clinical Neuroophthalmology, Vol. 2, 3rd edn., pp. 1357-1358. Williams \& Wilkins: Baltimore.

Worster-Drought, C. (1923). Herpes zoster with localised muscular paralysis. British Medical Journal, 1, 970-971.

Worster-Drought, C., and Sargent, F. (1949). Ophthalmic herpes zoster with contralateral pontine lesions. Medical Press, 221, 510.

Wray, S. (1972). Report from the New England Ophthalmological Society. American Journal of Ophthalmology, 73, 792.

Wynne Parry, T. G., and Laszlo, G. C. (1943). Herpes zoster ophthalmicus: two rare manifestations. British Journal of Ophthalmology, 27, 465-467.

Wyss, O. (1871). Beitrag zur konntais des herpes zoster. Arch. f. Heik., 12, 261 (BdXVI). 